\title{
Ageing in rural Brazil: a socio-demographic analysis of living conditions among black and white women and men
}

João Paulo Ferreira ( $\square$ joaopauloferreira@g.harvard.edu )

Harvard University

George Leeson

University of Oxford

Vivian Melhado

Universidade Federal de São Carlos

Article

Keywords: Rural ageing, Gender, Race, Social vulnerability, Inequality

Posted Date: February 23rd, 2021

DOI: https://doi.org/10.21203/rs.3.rs-259022/v2

License: (c) (i) This work is licensed under a Creative Commons Attribution 4.0 International License.

Read Full License 


\title{
Ageing in rural Brazil:
}

a socio-demographic analysis of living conditions among black and white women and men

\begin{abstract}
The aim of this article is to describe and analyse the general social conditions related to race/ethnicity, gender, class and schooling in a sample of 500 subjects ( $\mathrm{n}=250$ men; $\mathrm{n}=$ 250 women), aged 60 and over, who are Unified Health System users and resident in the rural area of a medium-sized city in São Paulo state. The methodological design was qualitative, grouping techniques to describe and analyse the selected categories intersectionally, making a sociological and critical analysis about old age in a rural context. For the data collection, we used a structured questionnaire with closed-ended questions concerning socio-demographic aspects. Using the IBM-SPSS Software (version 20.0), a database was produced with descriptive and specific information about the sample. The results corroborated different socio-demographic indicators between men and women, having significant distinctions for schooling and income to the detriment of the racial/ethnic profile of both groups. The conclusions attest profound social differences in the ageing process and old age in a rural context, radicalizing - unequally - from aspects related to "gender" and "race/ethnicity".
\end{abstract}

Key words: Rural ageing. Gender. Race. Social vulnerability. Inequality.

\section{Introduction}

Population ageing in Brazil is marked by diverse rhythms and flows, comprising heterogeneous processes of old age. According to projections by the Brazilian Institute of Geography and Statistics (IBGE, 2020), the Brazilian population is expected to grow by 2042, when the number of live births will be surpassed by the number of deaths. Thus, by 2060 , estimates indicate that the cohort aged 65 and over is likely to be $26.7 \%$ (58.4 million), and life expectancy will approach 81 years.

Considering a population growth to mid 2040 and the consequent prolongation of longevity, topics and themes related to old age have not only been privileged research objects in different areas of knowledge over the last two decades, but they have also given rise to paradoxes, challenges and dilemmas to public policies. According to data from the 2000 Demographic Census, there were gender differences in old age as more than $55 \%$ of the population aged 60 and over were women, increasing proportionately in relation to the age cohort. This has led authors from different areas to problematise "feminisation" of the more 
advanced stages of life, generating more consolidated discussions regarding the concept of "gender" of the social sciences to gerontology in Brazil (Britto da Motta, 1998; Debert, 1999; Camarano, 2003; Almeida et al., 2015).

The concept of race, considered as an analytical category (Hall, 2003), delineates multiple population groups and strata, whose articulation with the concept of "gender" enables us to detect variations and nuances regarding social differences from the perspective of ageing. According to Camarano (2003), one of the biggest concerns in old age comes from the fact that women over $60 \mathrm{yrs}$ demonstrate numerous vulnerabilities, either in relation to dependence due to pathologies and increased comorbidities or from an economic and social point of view.

In spite of this, Brito da Motta (1998) and Debert (1999) argue that old age conforms differently for men and women. While many men refer to this period of life as a resting time, having economic tranquility, socially engaging in groups and leisure activities, some women, especially widows and retirees, experience a new social reality, no longer necessarily restricted to the domestic environment, looking after the home and marital obligations. Many are still seen as caregivers, dividing their attention between the house, their spouse, giving assistance and support to parents and older relatives with some physical and/or psychic disability, helping to take care of grandchildren, etc.

The Social Indicators Synthesis report: an analysis of the living conditions of the Brazilian population, published in 2017 by the IBGE, revealed that a significant proportion of the elderly - a category that denotes men and women aged 60 and over, according to the National Elderly Policy (1994) - was retired. Concerning the income ratios, the report showed inequalities mainly related to access to employment income, pensions and retirement when combined with geographical origin, demonstrating more considerable vulnerability for the population from the North and Northeast regions, which have the lowest economic participation. This inequality, changing according to the territory, reaches considerable levels from segmentation by "race/ethnicity", and in 2016, among people who had a 10\% lower income, black or pardo were $78.5 \%$, and white $20.8 \%$ (IBGE, 2017).

Another important way of measuring this is the Multidimensional Poverty Index, which establishes an official line of measurement, as is the case of the methodology used in Brazil and Canada (Athias, Oliveira, 2016). Over the last two decades, in Brazil, several lines were used to measure poverty among the older population, such as indexes from the "Brazil 
without Extreme Poverty" and "Continuous Cash Benefit" programs, which also comprise policies and complementary budget laws. Calculating and estimating income from the lines have advantages and disadvantages; the difficulty of systematically updating the metrics for income may lead to imprecise and inadequate calculations, notably due to the increase or decrease in inflation and living standards, as well as the actual losses or gains of the minimum wage over time (IBGE, 2017).

Despite the many contingencies and transformations in the calculation, the measure works as a significant indicator at a global level, on a par with international research and reports, such as the 2030 Agenda $^{1}$, drawn up by the United Nations and the World Bank.

Age, taken as a criterion of measuring and allocating age groups, is a marker of vulnerability and, above all, inequality (Camarano, 2013). This leads us to consider that old age brings together different representations and realities when diluted among other categories of social difference, such as "gender", "race/ethnicity" and "class" - understood in this article as the marker "income".

This combination, taken in the scope of this research is inspired by the propositions made by Amartya Sen (1992), considering subjective measures of inequality and not necessarily economic from the monetary point of view, which are: (a) education (b) social protection, (c) adequate housing (d) basic sanitation services and (e) communication (internet access). In line with the United Nations report, 2017, poverty in Brazil has a higher incidence within the states, having an apparent improvement in living conditions when analysing the data available for the capitals; still according to the report, world poverty is $80 \%$ concentrated in rural areas.

According to the Continuous National Household Sample Survey (IBGE, 2017), restrictions on access to subjective measures (a, b, c, d, e) are more incidental in some population groups than in others, namely: black or pardo women, 60 yrs or above and black or pardo women, living without a spouse, and living with children up to 14 years old. In summary, the Continuous (IBGE, 2017) presents a relevant analysis of the sociological and

\footnotetext{
${ }^{1}$ The main aim of the 2030 agenda is to eradicate poverty in different forms and dimensions, especially extreme poverty, seeking alternatives for sustainable development. The text proposes 17 Sustainable Development Goals and 169 targets, aiming to cover a universal agenda. The new goals and targets are based on the Millennium Development Goals proposals, carried out by the United Nations Development Program in September, 2000, broadening and universalising their scope.
} 
demographic terms as it identifies people and population groups with diverse deprivations, configuring empirical data to consider broader issues that focus on social vulnerability.

Thus, this article looks at subjects older than 60 years, who currently live in rural areas in the interior of São Paulo state, providing a socio-demographic and comparative analysis of the indicators: "income", "schooling", "race/ethnicity" and "gender".

In Brazil and particularly São Paulo state, in the late 1960s, there was a wave of migration from the countryside to the cities due to introducing a new way of production in the countryside, which resulted in thousands of families being evicted from squatters, settlers, tenants and partners. People evicted in the context of what has been termed "conservative modernization" or "green revolution", characterised by using technology in the countryside, were directed to urban outskirts. Many of them became seasonal farm workers or temporary workers who lived in the cities and worked in the countryside (Silva, 1999).

However, many families and different populations - especially the oldest - remained in the countryside, living with the paradoxes of "modernization", as well as low centered development indicators, historically, low per capita income and schooling. Therefore, as Avtar Brah suggested (1996), we intend to demonstrate how the experiences that populate the "old age" category in rural contexts are polymorphous, heterogeneous and unequal, insofar as the concept of "race/ethnicity", in dialogue with the concepts of "class", "gender" and "schooling", presents itself as an ineradicable marker of social difference in the studied population.

On principle, the question of old age in the countryside is understood as problematic, and the following questions are asked: what are the social indicators and general sociodemographic conditions concerning "gender", "schooling", "income" and "ethnicity", between men and women aged 60 and over, inhabitants of rural areas? Would there be differences, intersectionally, between men and women based on socio-demographic data? To what extent does racial/ethnic profiling (or not) comprise differences and even an extent of vulnerability in the rural population?

\section{Methodological approach}

The research comprised qualitative design, which combined different methods and techniques for data collection and analysis. The study was conducted in the reception and 
screening area of a federal hospital, located in a medium-sized city in São Paulo state. Based on structured interviews, the sample consisted of a sample of 500 subjects (men $=250$; women $=250$ ), aged 60 and over, who lived with their family and were attended by the Unified Health System (SUS). In order to establish the racial/ethnic criteria, the research was divided as follows: from the group of men ( $n=250), 125$ subjects called themselves "white" and 125 called themselves "black". The same applied to the group of women $(n=250)$, in which 125 called themselves "white" and 125 called themselves "black".

In addition, the research followed the essential ethical recommendations and was approved prior to data collection by the Human Research Ethics Committee from the Federal University of São Carlos (CAAE No. 57988116.0.0000.5504). The steps of this research adhered to the guidelines of Resolution 196/96 and 466/2012 of the National Health Council.

\section{Results}

Income

The predominant income between the two groups ( $\mathrm{n}=250$ men; $\mathrm{n}=250$ women) was a minimum wage - a value relative to retirement for individual taxpayers. In the first sample (Table 1), comprising men, the composition of the income sources varied, and in general terms, 18 subjects reported formal work, 42 informal work, 111 survived on a retirement pension, 43 on allowances, 17 on Continuous Cash Benefit and 19 on other income source(s).

In the second sample comprising women, the composition of income sources remained prominent among those who declared that they survived on a retirement pension $(\mathrm{n}=79)$, even though there was a significant reduction in quantitative terms when compared to the group of men ( $\mathrm{n}=111, \mathrm{SD}: 16)$. Therefore, there was a significant increase relative to informal work in contrast to men, while 63 women reported having an income from informal work (SD: 10.5). It was also possible to measure an increase in the composition of allowances among women $(\mathrm{n}=58$, SD: 7.5).

In the division by "gender" and "race/ethnicity", the data presented revealing information, which pointed to substantial inequalities between the two groups. For the first group of men, we attributed two independent variables to the composition of income 
sources: $\left(1^{\text {st }}\right)$ self-declared as black $(\mathrm{n}=125)$ and $\left(2^{\text {nd }}\right)$ self-declared as white $(\mathrm{n}=125)$. The same applied to the second group consisting of women.

Starting with the second variable of the first group, comprising men self-declared as white, we found that a large proportion inferred income through retirement pension $(\mathrm{n}=$ 62), followed by allowances $(n=19)$, informal work $(n=17)$, formal salaried work $(n=13)$, other source $(\mathrm{s})(\mathrm{n}=8)$ and Continuous Cash Benefit $(\mathrm{n}=6)$. The first variable, comprising individuals self-declared as black, presented quantitative differences in relation to the previous data, notably by the relative reduction in the number of subjects who inferred income from a retirement pension $(\mathrm{n}=49 ; \mathrm{SD}: 6.5)$. On the other hand, there was an increase in the composition of income sources for informal work ( $\mathrm{n}=25$; SD: 4$)$ and a reduction of the indicator by formal salaried work $(n=5$; SD: 4$)$ in contrast to individuals self-declared as white.

However, the group of women also presented differences concerning the composition of income sources between the two variables referring to "race/ethnicity". Starting with the second, with women self-declared as white, a predominance of income sources was observed due to retirement pension $(n=46)$ and allowances $(n=30)$, income from informal work $(n=26)$, formal salaried work $(n=12))$ and, to a lesser extent, other source $(\mathrm{s})(\mathrm{n}=8)$ and Continuous Cash Benefit $(\mathrm{n}=3)$. Concerning women self-declared as black, the data had significant changes, corroborating differences in the income profile concerning "race/ethnicity"; in this aspect, an increase in income through informal work can be seen ( $\mathrm{n}=25$; SD: 4$)$ and a decrease in the number of workers who earn an income from formal salaried work $(n=5 ;$ SD: 4). There was also a significant decrease in the number of women who inferred retirement pension ( $\mathrm{n}=49$; SD: 6.5), followed by an increase in allowances ( $\mathrm{n}=24$; SD: 2.5), Continuous Cash Benefit ( $\mathrm{n}=11$; SD: 2.5$)$ and other source(s) of income ( $\mathrm{n}=11$; SD: 1.5$)$.

\section{Schooling}

Concerning schooling, comprising the two samples, 59.4\% ( $\mathrm{n}=297$; SD: 24.5) said they were illiterate, $23.8 \%$ ( $\mathrm{n}=11$; SD: 11.5) did not complete basic education (basic education means from 6-14 years old), 15\% ( $\mathrm{n}=75$; SD: 10.5$)$ completed basic education and $1.8 \%(\mathrm{n}=9$; SD: 2.5) finished secondary school (14-18 years old). However, when the data concerning schooling were grouped according to the "gender" category, according to Table 2, a 
significant difference can be observed in quantitative terms, reflecting discrepant indicators among the four levels of schooling measured, as the women interviewed occupied unequal positions, with fewer years of study and, consequently, a higher prevalence of illiteracy (Figure 1).

When the two samples are stratified by "gender" and "race/ethnicity", new paradoxes and differences emerge in relation to the general schooling data. In the first group, comprising men self-reported as black $(n=125)$ and self-declared as white $(n=125)$, the "race/colour" criterion indicates that individuals self-reported as white have higher schooling indicators (Table 2). Among those who declared themselves as white, 56 inferred illiteracy, 33 incomplete basic education, 31 completed basic education and 5 finished secondary school. Respondents self-reported as black, however, presented higher indicators of illiteracy ( $n=68$; SD: 6$)$ and incomplete basic education ( $\mathrm{n}=38$; SD: 2.5). However, there was a reduction in the data for complete basic education ( $\mathrm{n}=17$; SD: 7 ) and those who finished high school ( $\mathrm{n}=2$; DP: 1.5). To sum up, the data show that, although the "illiteracy" indicator is commonly high in both samples, there are also differences between the two variables in racial terms, confirming that individuals self-reported as black have lower schooling than subjects self-reported as white (Figure 2).

In the second group, comprising women self-declared as black and self-declared as white, there are significant differences regarding the "race/ethnicity" variable. Starting from the second variable, relative to women self-declared as white, there was a prevalence of illiteracy ( $\mathrm{n}=75)$, followed by incomplete basic education $(\mathrm{n}=31)$, complete basic education $(n=17)$ and finished secondary school $(n=2)$. The data for the second variable, which joins women self-declared as black, in contrast, increased the differences related to illiteracy, showing that women in this group are mostly illiterate ( $\mathrm{n}=98$; SD: 11.5).

Concerning women self-reported as black with some schooling, data are lower than those obtained in the first group (relative to women self-declared as white) as only 17 respondents reported incomplete basic education (SD: 7) and 10 with complete basic education (SD: 3.5). Furthermore, data for those who finished secondary school do not exist in this sample. Thus, it is possible to distinguish between the schooling profile in the two subgroups, whose indicators are radicalized by the "race/ethnicity" criterion, demonstrating that women self-declared as black are unequivocally more vulnerable regarding schooling (Figure 3). 
Compared to the group of men self-reported as black, women self-reported as black also presented lower data, as can be observed in Figure 4. That is, data by "gender" and "race/ethnicity" show stark inequalities concerning schooling, while women self-reported as black, in all possible scenarios for the studied population, have the lowest schooling rates.

\section{Discussion}

Gender, income and schooling in a rural setting: making an analysis about the race/ ethnicity spectrum in old age

The socio-demographic profile found for both groups presented significant differences in relation to the "gender" category, which enables us to reflect on the "gender" category as a prominent marker of social difference. Furthermore, the data attest our initial hypothesis that there would be distinctions concerning the variables "class" and "schooling" for men and women.

In spite of the differences related to gender, generally the elderly population in Brazil represents the poorest population cohort with the lowest rate of schooling (Camarano, 2003, IBGE, 2017). Authors such as Silva (1997) and Faleiros (2007) analysed that this reality, has disparities in terms of having access to fundamental resources, such as the lack of treated water, electricity and access to child and adult education.

From the data obtained, an even more problematic panorama for new research and the setting of ageing in the field can be observed from the differences between "race/ethnicity". The mere territorial equation between elderly subjects living in urban areas versus those living in the countryside does not seem to account for heterogeneous realities, especially in Brazil, having a historical process of discrimination, stigma and enslavement of the black and often poorer population with low schooling (IBGE, 2000, 2017). Thus, the "race/ethnicity" variable corroborated significant differences concerning the composition of income and schooling, which is part of the gender problem, showing that women over 60 and those self-declared as black have a lower income and the worst indicators for education in the possible multiple comparison scenarios. This data, in line with what was briefly introduced in the introduction by the Continuous National Household Sample Survey (IBGE, 2016) and the Social Indicators Synthesis (IBGE, 2017), includes a portion of socially vulnerable subjects, mostly represented by black and pardo women over 60 years. 
Although there is a prevalence of retired women $(\mathrm{n}=79)$, men have a higher proportion of retirement pension $(\mathrm{n}=111)$. Having said that, in this context, women do informal work ( $\mathrm{n}$ =63) when they are elderly much more than men $(n=42)$ do in order to compensate for the lack of social security and managing to survive. These data show that women selfdeclared as black $(\mathrm{n}=37$ ) rely more on informal work for income than women self-declared as white $(\mathrm{n}=26$; SD: 5.5$)$ in the same age bracket.

In historical terms, rural workers were only entitled to retirement under the 1988 Constitution. Before that they were protected by Funrural ${ }^{2}$, which guaranteed them a few benefits. This fact contributed to the precariousness of rural workers. Therefore, the social class dimension is in this case quite explicit in the sense of increasing the social inequality of these workers compared to the others (Silva, 1999).

Woortmann \& Woortmann (1999) argue that income obtained from social security is fundamental for maintaining basic living conditions; i.e. buying medicine, food, clothing and household utensils, especially in circumstances of extreme drought, disaster or the reduction of rural production (especially in situations where families make a living from producing organic vegetables, animals and other soil-dependent food products).

Thus, if retirement is an indispensable resource in the event of a shortage of formal labour and natural resources, sickness and climate change whose effects directly affect small farmers and the informal economy from family agriculture, it can be observed that this nonminority share of underprivileged social security subjects are to a large extent in a situation of social vulnerability. Moreover, they are people who have had their trajectories marked by exploitation in the extensive agglomerations of sugarcane, orange picking, soybeans and coffee plantations, ageing, therefore, with numerous comorbidities, as a result of hard work and the precariousness of living conditions in the countryside in the last century (Silva, 1999; 2014; 2016).

As of the 1988 Constitution, the rural social security system is no longer a priority for welfare policies, refractory to Funrural, with reduced options and benefits, moving to a macro policy centered on social and universal protection, with the principles of citizenship and the same rights granted to workers in an urban context.

\footnotetext{
${ }^{2}$ Rural Workers Assistance Fund.
} 
Laws 8.212 and 8.213, enacted in 1991, also modify the way the family unit (husband, wife and children aged 16 and over) obtains access to Social Security funds. This change started to integrate the whole family in the context of politics, thus no longer an exclusive resource for a minority of subjects. Before the two laws mentioned above, rural workers were only entitled to a retirement and death pension, starting to count (from the Social Security) on the same benefits paid to workers in urban areas, among which were: sickness, maternity pay and retirement pension due to disability. Finally, another crucial point was the equalisation of the social security, guaranteed by the Constitution, from a common minimum wage, levelling the minimum importance of the benefits granted to rural and urban workers ${ }^{3}$.

The vulnerabilisation of the poorest and oldest population in generational terms, considered sociologically, encompasses a process that began in the mid-1950s in São Paulo state, from replacing coffee farms with large sugarcane mills (Silva, 1999; 2014; 2016). Concerning this process:

\footnotetext{
"Thousands of agricultural workers left their land to work in the sugar plantations of São Paulo state. Many left the family behind as a way of guaranteeing social reproduction. Those victimised by the expropriation of their land came with their families. This fact caused a change in the chromatic aspect of the rural working class of São Paulo. Descendants of European and white settlers were no longer on the scene, but rather 'people of the northern countries', 'people from Bahia', 'people from Minas Gerais' and the 'blacks'. From its beginnings, work in sugarcane plantations was characterised by precariousness, insalubrity and vulnerability." (Silva, 2016, p.149).
}

The outskirts of the sugarcane cities of São Paulo state are inhabited by significant population contingents from other regions of the country and, in many cases, this process characterizes a significant portion of black migrants. In the case of the city where the research was carried out, a neighbourhood on the outskirts was created in the mid-1980s by people from the Northeast, Minas Gerais, Paraná, etc. (Maciel, 2012). They are agricultural workers expropriated from their lands of origin, as a consequence of the conservative modernisation that affected the whole country (Silva, 1999; 2016).

Concerning this, according to Baeninger (1995), the great region that covers the territory of the research, had 75,871 migrants in the 1970s, which corresponded to 58,105 
people from São Paulo state and 17,766 from other states. Baeninger (1995) and Maciel (2012) found that the migratory process intensified in 1980, 1990 and 2000, leading to the population of the cities that make up the Government Region of Araraquara to double in size from 238,327 to 569,404 inhabitants in 2010.

Since the 1950s, the rate of urbanisation has increased and, for the first time, the rural population of 47,958 inhabitants is lower than the urban population of 50,628 inhabitants (Maciel, 2012). Baeninger (1999) considers that the migratory balance to the region in question contributed with $67.7 \%$ of the absolute growth of the Government Region, i.e., an increase of 40 thousand inhabitants. The migration phenomenon related to looking for work and better living conditions in the 1960s and 1970s was cleaved by the gender component, while many men and women - usually wives - migrated to the former settlements and coffee, soy, corn, cotton and sugar cane production regions, performing equally heavy, unhealthy and dangerous task ${ }^{4}$. With the growth of agricultural modernisation, there was an abrupt change in the old coffee structure, also changing the structure of work and organisation of social life in the countryside.

Thus, the work force of the new migrants was added to the strength of those who already lived in rural areas of São Paulo state (Stolcke, 1986; Silva, 1998; Alves, 1991; Maciel, 2012).

Women, historically constrained from the universe of formal salaried work (Saffioti, 1976), used more strategies to earn a family income, either by informal work or federal benefits, such as the Continuous Cash Benefit. This benefit, established by the Unified Social Assistance System, was created in December 1993, based on the Organic Law of Social Assistance, as a way of guaranteeing a minimum wage to people 65 and over, as well as to people with disabilities, who have per capita family income below a quarter of a minimum wage (Alcântara, 2016).

Public policies focused on security in Brazil have created a distinct social situation for families and people who, in the past, were marginalised in income and access to services. The great change, initiated by the Federal Constitution of 1988, from the first writings on social security and old age, favoured and encouraged the emergence of complementary

\footnotetext{
${ }^{4}$ Silva's research (2016, p.156-157), undertaken in the same region in which we are concerned with in this article, recovers the gender division of labour in the countryside. The author discusses the unhealthy, heavy and invisible nature of the tasks performed by women; namely: administering herbicides, harvesting sugarcane crushed by machines, removing weeds from the sugarcane plantations, planting new sugarcane seedlings and picking up stones.
} 
legislation, such as the National Policy on the Elderly in January 1994, the Statute on the Elderly in October, 2003 and the National Policy on the Health of the Elderly in October, 2006 (Debert, 1999; Camarano, 2003; Faleiros, 2007; Alcântara, 2016).

According to demographic census data from 1940 and 2000, the female contingent above 60 years old accounted for $4.7 \%$ of the total Brazilian population in 2000, compared to $2.2 \%$ in 1940 ; the male population, also above 60 years old, was at the lowest proportion in 2000 at 3.8\%. Concerning the population considered "very old" - made up of subjects aged 80 and over - it was 166 thousand people in 1940 compared to approximately 1.8 million in the 2000s. The "very old" female population in the 2000 s, accounted for $12 \%$ of this cohort in Brazil (Faleiros, 2007; Beltrão et al., 2003; Veras, 2009; Alcântara, 2016).

According to Camarano (2003), the portrayal of the female cohort considered "elderly" and "older" in the country is characterised by the lack of experience in the formal labour market and by the low level of schooling, constituting worse health conditions. From the educational perspective, the IBGE, through the Continuous National Household Sample Survey (IBGE, 2016), compiled new data on illiteracy and the differences between race/ethnicity in the population, starting a series of comparisons never seen in historical terms. According to the results obtained, people self-declared as white - in all age cohorts have more access to education in the country than those who are self-declared as blacks or pardo, and the oldest population join together the largest contingent of illiterate people, making up 6.07 million people.

When the data of the Continuous National Household Sample Survey (IBGE, 2016) are stratified between subjects aged 60 and over by race/ethnicity, the differences widen between whites, blacks or pardos. In the cohort of white subjects, the illiteracy indicator corresponds to $11.7 \%$, while the indicator between blacks and pardo in the same age group almost triples, approaching $30.7 \%$.

This data engenders approximations with the results obtained from the research, with differences in schooling between individuals self-declared as white and black, but with an unprecedented data on gender, in which women self-declared as black have the worst indicators of both income and educational level compared to men self-declared as white and black, within the same age group. Nonetheless, women self-declared as black reported income from a retirement pension, informal work and Continuous Cash Benefit, while men 
were proportionately more retired, with more experience in the formal job market, in addition to having higher educational indicators. Thus:

\footnotetext{
"older women receive benefits in less privileged conditions than men: retirement by age versus length of service and benefits. The value of such benefits is lower. This situation reflects the greater precariousness of the female condition in the labour market. The ways in which, historically, additional protection for women in social security terms has been created (shorter working or contribution time, lower eligibility for benefits, widows' full pension entitlement) should not be seen as compensation only for the double shift but also because of the precariousness of women's working conditions relative to men." (Camarano, 2003, p.44).
}

From the 1980 s to the 2000s, the percentage of women without any income fell significantly from $42.2 \%$ to $18.4 \%$, with the proportion of poor women also reducing by 21.3 percentage points, totalling a reduction of 56\% (IBGE, 2000, Camarano, 2003). However, contrary to the 1998 National Household Sample Survey/IBGE data, women in the survey conducted here represented the poorest stratum compared to men with a significant reduction in income from the "race/ethnicity" marker, as women self-declared as black were at a disadvantage compared to the other groups (IBGE, 2000; Camarano, 2003).

Differently from Beltrão et al. (2003) and Camarano (2003), where the data on the racial/ethnic profile did not show significant differences in terms of income - even though there was a higher proportion of white women living without income - the present study showed significant differences for the variable "race/ethnicity", putting forward a new empirical and theoretical proposition to demography. Camarano (2003) argues that although there have been no quantitatively significant differences concerning the racial/ethnic profile in the 2000 Census survey, the effect of the race/ethnicity category can be found in relation to the proportion of elderly women living in households considered poor; in the research, the author analyses that slightly more than $25 \%$ of black and pardo women resided in such housing.

The "work" category, in light of Silva's research $(1999 ; 2014 ; 2016)$ is an important marker of social difference and reproduction as the gender division of labour creates new inequalities in relation to ageing in the field. According to Silva (2014; 2016), "gender", "class" and "race/ethnicity" are analytical concepts that must be thought and mobilised in a 
relational and dynamic way as they configure asymmetrical paradoxes and relations, relative to the way the world of life is created and reproduced.

In this regard, it should be pointed out that while policies focused on social security have ensured progress in terms of income distribution, education and improved living conditions over the last 30 years, there are still challenges regarding gender differences and the racial/ethnic profile of the Brazilian population over 60 living in a rural context.

Regarding differences, we can see the discrepancy of the socio-demographic profile in terms of schooling and income, configuring a distinct social situation between the analysed groups, mainly from the racial and gender aspect; concerning the similarities, in turn, approximations can be observed with the official data produced by the 2000 Census, Continuous National Household Sample Survey (IBGE, 2016) and by the Social Indicators Synthesis (IBGE, 2017), as well as by the specialised literature as the total sample is still represented by the spectrum of illiteracy and low professionalization. This creates a social and economic gap between those whose childhood, youth and part of adult life were before the Federal Constitution (FC) and, therefore, without legal guarantees of rights, and those subjects who were born after the promulgation of the FC, having their generational experience marked by democratic governments and social policies centered on social security, expansion of education, economic growth, severe reduction of hunger and extreme poverty, increased social mobility and of labour rights.

\section{Preliminary considerations}

To sum up, the results showed differences concerning the "ethnic/racial" and "gender" profile regarding the variables of "schooling" and "income" among the elderly, leading us to problematise such categories and propose an articulated analysis, based on the national indicators produced by the IBGE and social sciences and demography literature. In general, there is an uneven situation between men and women, and more in-depth socio-demographic differences when the sample is stratified by "race/ethnicity", showing that women selfdeclared as black present the worst indicators for both income and schooling.

Therefore, "race/ethnicity" is an indispensable marker of analysis on the issue of social vulnerability, bringing together significant differences when combined with other categories such as "gender" and "class", for example. As a limitation of the study, we 
highlight the lack of data that can explain the issues associated to housing structure, basic sanitation services and communication networks as equally impacting measures and that include the pillars of the Social Vulnerability Index. Thus, we consider that, despite the important contributions on income composition and schooling presented here, there is a need for further investigations and research that consider other items to obtain more robust data and new clues on the issue of social vulnerability in Brazil.

It can be concluded, preliminarily, that despite the laws and complementary benefits, differences in racial and gender terms still persist in old age, which is a problematic situation from the social and economic point of view. Historically exploited individuals and groups from the countryside to the city - live in the most advanced stages of life with the contradictions of a still unequal society in which "women", "blacks" and "old people" survive without recognised full citizenship.

\section{References}

Alcântara, A. (2016). Envelhecer no contexto rural: a vida depois do aposento. In: A. O. Alcântara, A. A. Camarano \& K. C. Giacomin. (Eds.), Política Nacional do Idoso. Rio de Janeiro: IPEA.

Almeida, A. V., Mafra, S. C. T., Silva, E. P. \& Kanso, S. (2015). A feminização da velhice: em foco as características socioeconômicas, pessoais e familiares das idosas e o risco social. Textos \& Contextos, 14(1): 115-131.

Alves, F. J. C. (1991). Moderniz̧ação da agricultura e sindicalismos. Campinas: Unicamp.

Athias, L. \& Oliveira, L. (2016). Indicadores de padrão de vida e distribuição de renda. In: A. Simões \& B. Fresneda. (Eds.), Panorama nacional e internacional da produção de indicadores sociais. Rio de Janeiro: IBGE.

Baeninger, R. A. (1999). Região, metrópole e interior: Brasil, 1980-1996. Campinas: Unicamp.

Beltrão, K. I., Pinheiro, S. S., Leme, F. P. \& Mendonça, J. L. O. (2003). Desigualdades que perduram. Rio de Janeiro: mimeo.

Brah, A. (1996). Cartographies of diaspora. Routledge: London. 
Brasil. (2000). Censo demográfico. Brasília: IBGE.

Brasil. (2017). Sintese de indicadores sociais: uma análise das condições de vida da população brasileira. Brasília: IBGE.

Britto da Motta, A. (1998). Chegando pra idade. In: M. L. Barros (Ed.), Velhice ou terceira idade? Rio de Janeiro: FGV.

Camarano, A. A. (2003). Mulher idosa: suporte familiar ou agente de mudança? Estudos Avançados. São Paulo, 17: 17-35.

Debert, G. G. (1999). A reinvenção da velhice: socialização e processos de reprivatização do envelhecimento. São Paulo: EDUSP.

Faleiros, V. P. (2007). Cidadania: os idosos e a garantia de seus direitos. In: A. L. Neri. (Ed.), Idosos no Brasil. São Paulo: Editora Fundação Perseu Abramo.

Hall, S. (2003). Da diáspora. Belo Horizonte: Editora da UFMG.

Maciel, L. M. (2012). O sentido de melhorar de vida: arranjos familiares na dinâmica das migrações rurais-urbanas em São Carlos-SP. Campinas: Unicamp.

Saffioti, H. (1976). A mulher na sociedade de classe: mito e realidade. Petrópolis: Vozes.

Sen, A. K. (1992). Inequality re-examined. Oxford: Clarendon Press.

Silva, M. A. M. (1999). Errantes do fim do século. São Paulo: Edunesp.

Silva, M. A. M. (2014). A nova morfologia do trabalho nos canaviais paulistas. In: R. Antunes. (Ed.), Riqueza e miséria do trabalho no Brasil. São Paulo: Boitempo.

Silva, M. A. M. (2016). Trabalho rural: as marcas da raça. Lua Nova, Revista de Cultura e Política. São Paulo, 99: 139-167. Doi: 10.1590/ 0102-6445139-167/99

Silva, J. G. (1997). O novo rural brasileiro. Nova Economia. Belo Horizonte, 7(1): 43-81.

Stolcke, V. (1986). Cafeicultura. Homens, mulheres e capital (1850-1980). São Paulo: Brasiliense.

United Nations. (2017). Sustainable development goals. New York: UM. 
Veras, R. (2009). Envelhecimento populacional contemporâneo. Revista de Saúde Pública. São Paulo, 43: 548-554.

Woortmann, E. \& Woortmann, K. (1999). Velhos camponeses. Revista Humanidades. Fortaleza, 46: 132-141. 
Table 1

Composition of the income sources of the subjects by gender and race/ethnicity (2018-2020).

\begin{tabular}{|c|c|c|c|c|c|c|c|}
\hline & $\begin{array}{c}\text { Formal } \\
\text { salaried } \\
\text { work }\end{array}$ & $\begin{array}{l}\text { Informal } \\
\text { work }\end{array}$ & $\begin{array}{c}\text { Retirement } \\
\text { pension }\end{array}$ & Allowance & $\begin{array}{l}\text { Continuous } \\
\text { cash benefit }\end{array}$ & Other & Total \\
\hline Men & 18 & 42 & 111 & 43 & 17 & 19 & 250 \\
\hline Women & 16 & 63 & 79 & 58 & 7 & 27 & 250 \\
\hline Total & 34 & 105 & 190 & 101 & 24 & 46 & 500 \\
\hline Standard Deviation & 1 & 10.5 & 16 & 7.5 & 5 & 4 & \\
\hline \multicolumn{8}{|l|}{ *Men } \\
\hline Self-declared as black & 5 & 25 & 49 & 24 & 11 & 11 & 125 \\
\hline Self-declared as white & 13 & 17 & 62 & 19 & 6 & 8 & 125 \\
\hline Standard deviation & 4 & 4 & 6.5 & 2.5 & 2.5 & 1.5 & \\
\hline \multicolumn{8}{|l|}{ *Women } \\
\hline Self-declared as black & 5 & 37 & 35 & 25 & 4 & 19 & 125 \\
\hline Self-declared as white & 12 & 26 & 46 & 30 & 3 & 8 & 125 \\
\hline Standard deviation & 3.5 & 5.5 & 5.5 & 2.5 & 0.5 & 5.5 & \\
\hline
\end{tabular}

Source: Developed by the authors from a database. 
Table 2

Schooling indicators by gender and race/ethnicity (2018-2020).

\begin{tabular}{|c|c|c|c|c|c|}
\hline & Illiterate & $\begin{array}{c}\text { Did not } \\
\text { complete basic } \\
\text { education }\end{array}$ & $\begin{array}{c}\text { Completed } \\
\text { basic education }\end{array}$ & $\begin{array}{c}\text { Finished } \\
\text { secondary } \\
\text { school }\end{array}$ & Total \\
\hline Men & 124 & 71 & 48 & 7 & 250 \\
\hline Women & 173 & 48 & 27 & 2 & 250 \\
\hline Total & 297 & 119 & 75 & 9 & 500 \\
\hline Percentage & 59.4 & 23.8 & 15 & 1.8 & 100 \\
\hline Standard Deviation & 24.5 & 11.5 & 10.5 & 2.5 & \\
\hline \multicolumn{6}{|l|}{${ }^{*}$ Men } \\
\hline Self-declared as black & 68 & 38 & 17 & 2 & 125 \\
\hline Self-declared as white & 56 & 33 & 31 & 5 & 125 \\
\hline Standard Deviation & 6 & 2.5 & 7 & 1.5 & \\
\hline \multicolumn{6}{|l|}{ *Women } \\
\hline Self-declared as black & 98 & 17 & 10 & 0 & 125 \\
\hline Self-declared as white & 75 & 31 & 17 & 2 & 125 \\
\hline Standard Deviation & 11.5 & 7 & 3.5 & 1 & \\
\hline
\end{tabular}

Source: Developed by the authors from a database. 


\section{Figure 1}

Schooling indicators between men and women.

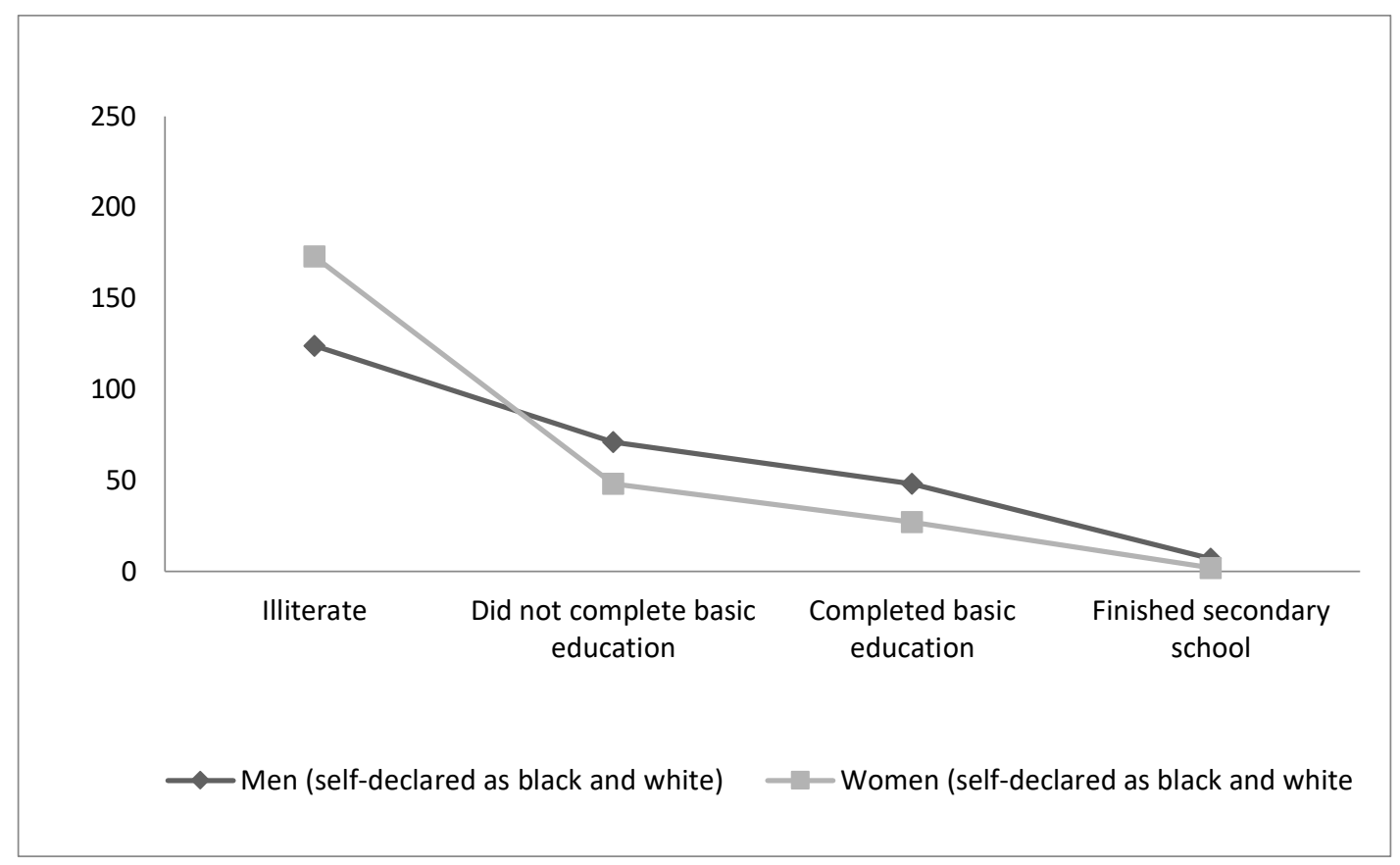

Source: Developed by the authors from a database. 
Figure 2

Schooling indicators among men by race/ethnicity.

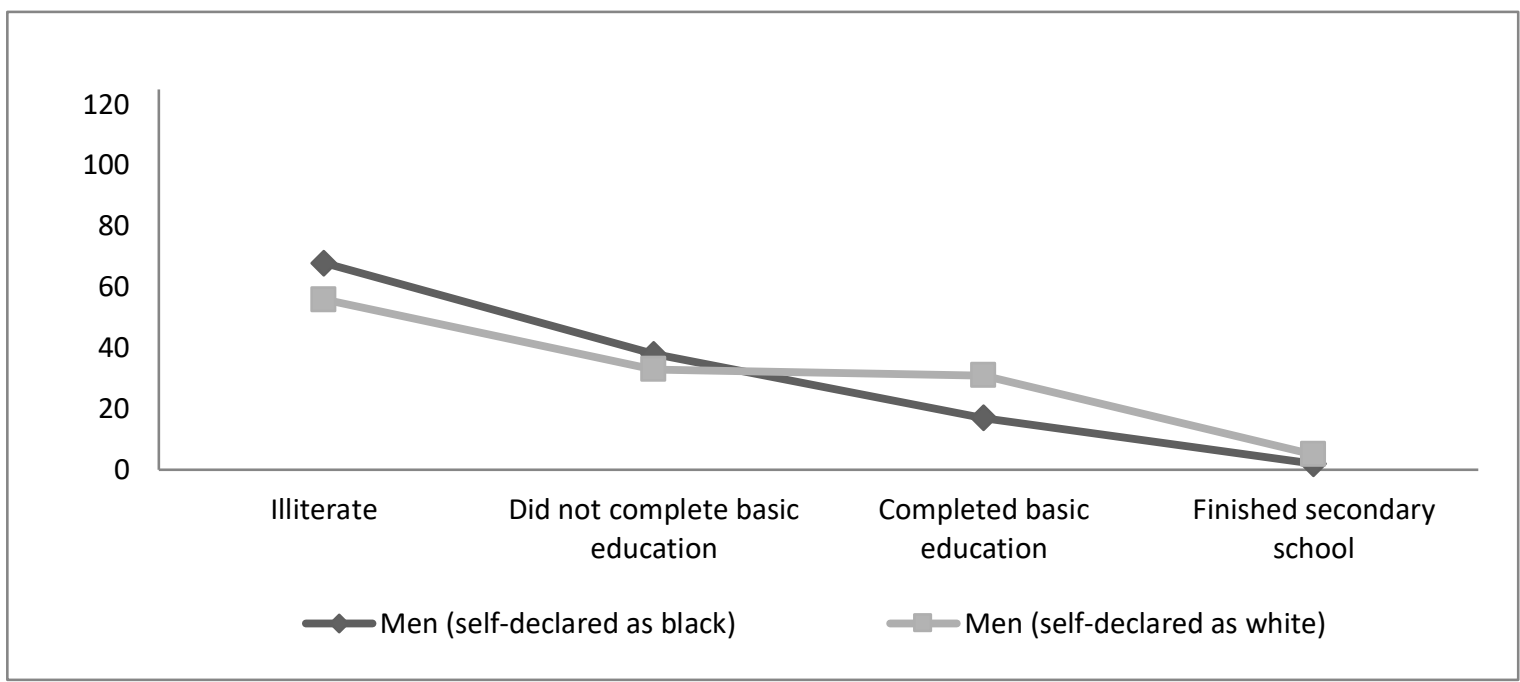

Source: Developed by the authors from the database. 
Figure 3

Schooling indicators among women by race/ethnicity.

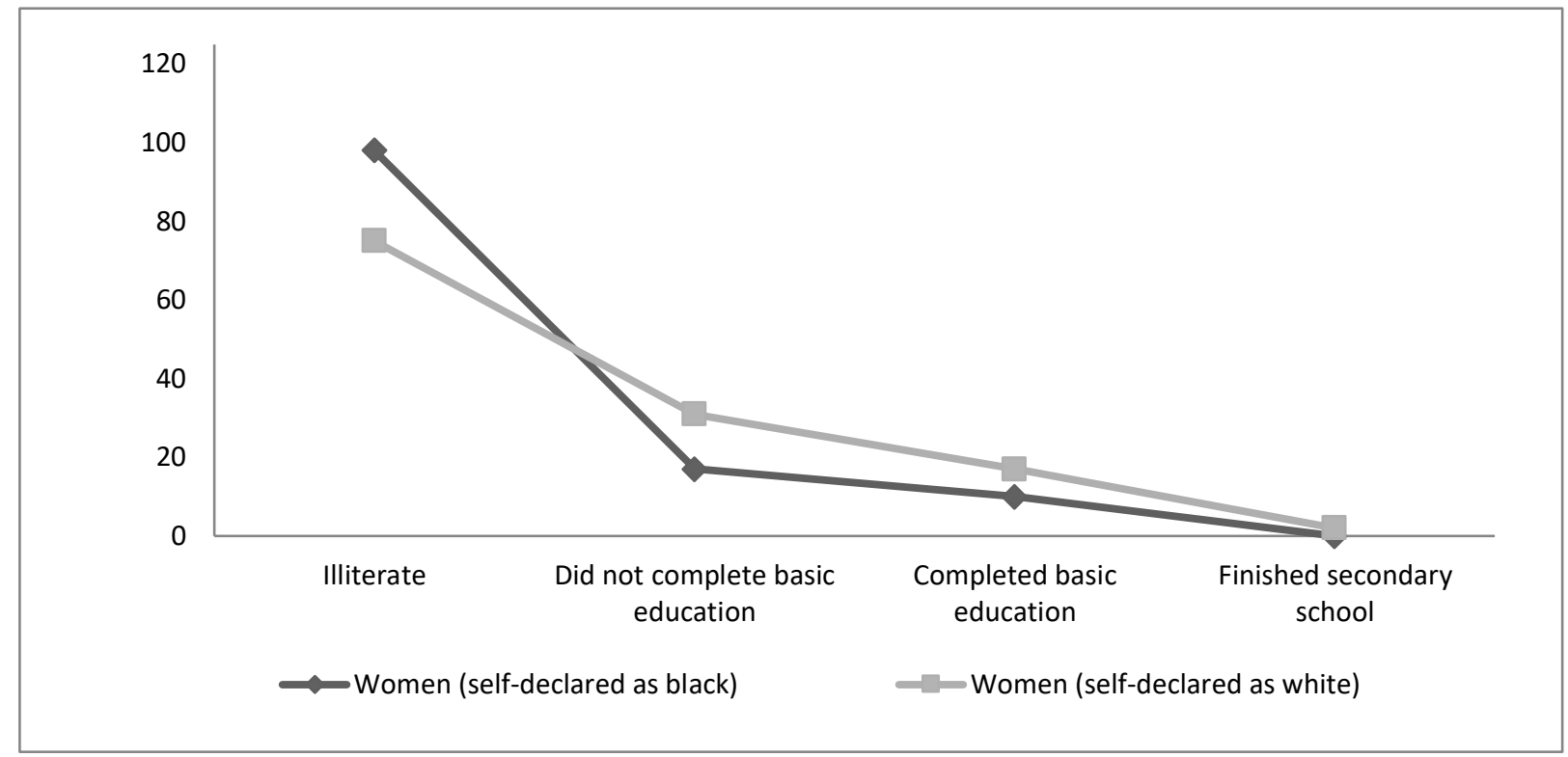

Source: Developed by the authors from the database. 


\section{Figure 4}

Schooling indicators among men and women self-reported as black.

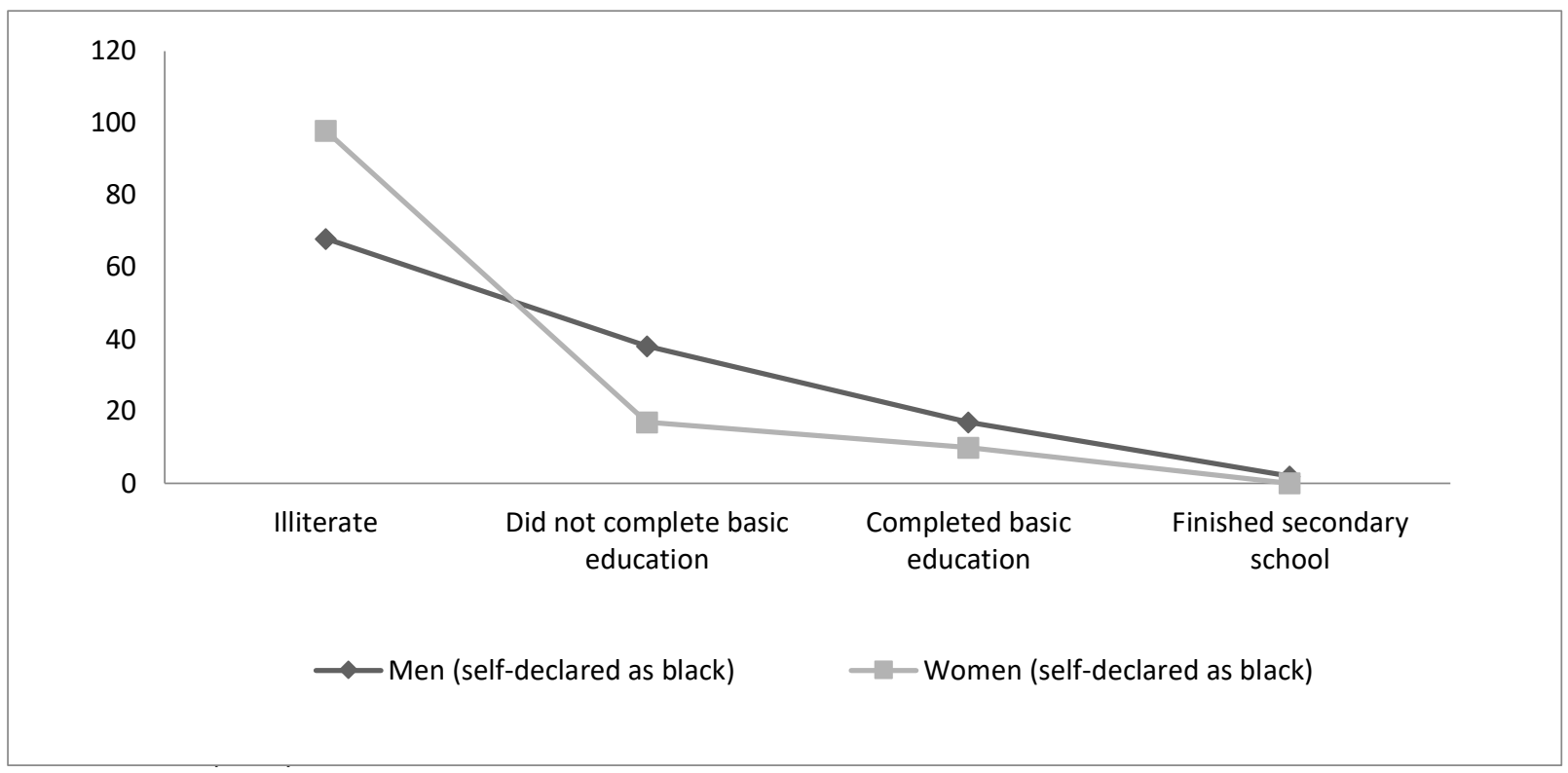

Source: Developed by the authors from the database. 


\section{Figures}

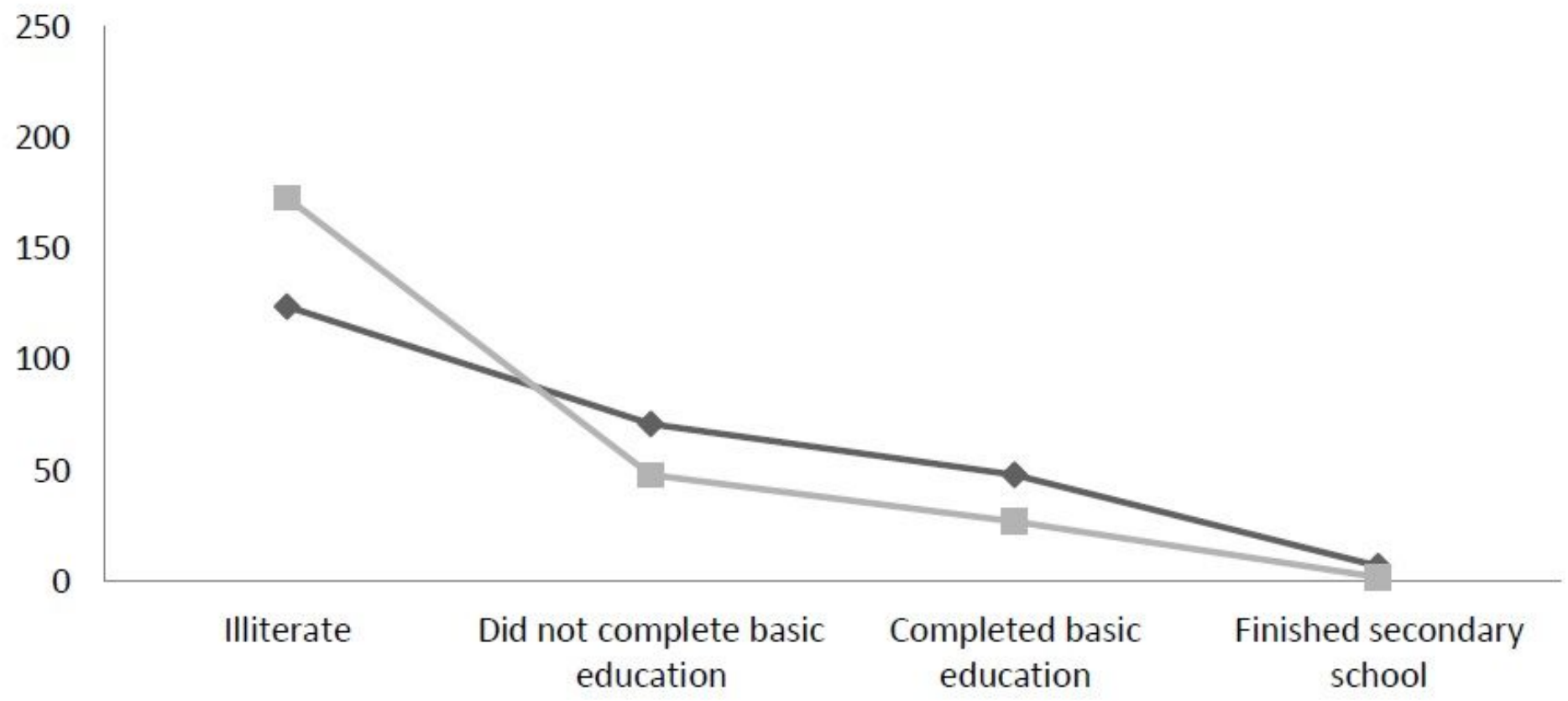

\section{Figure 1}

Schooling indicators between men and women. Source: Developed by the authors from a database.

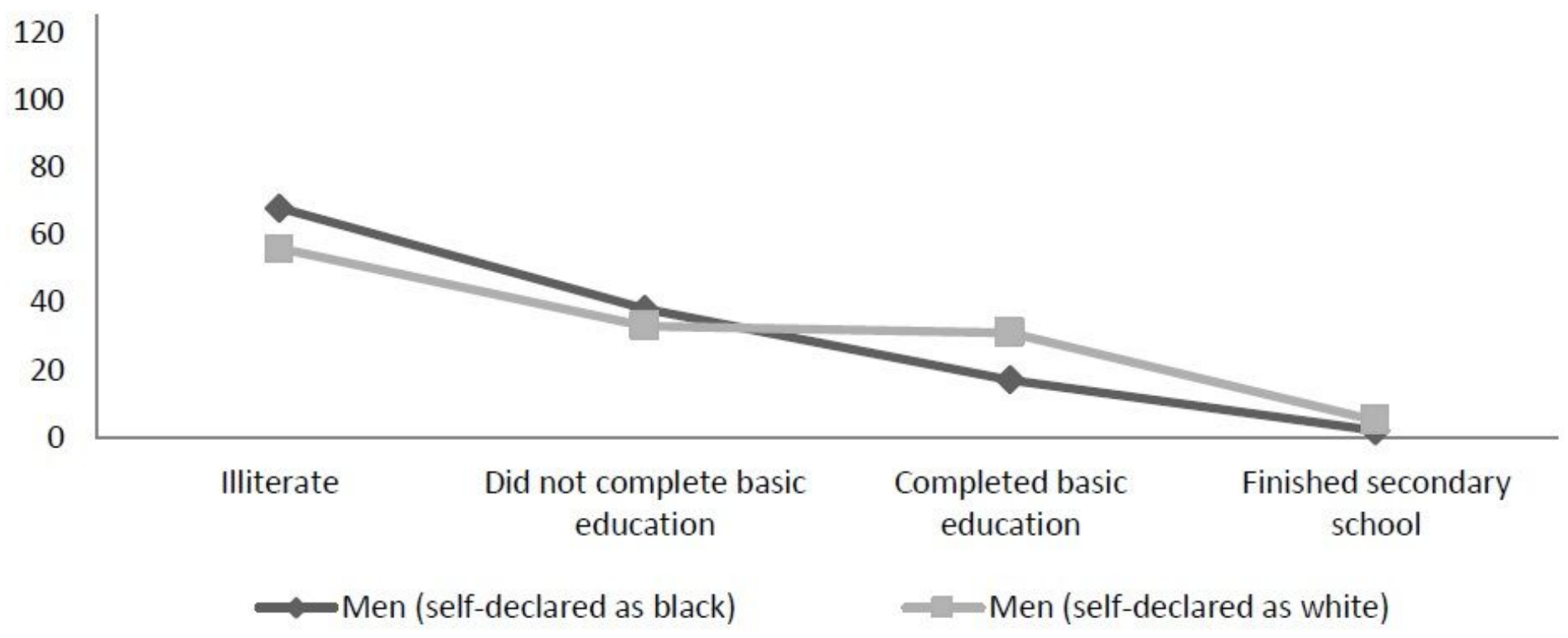


Schooling indicators among men by race/ethnicity. Source: Developed by the authors from the database.

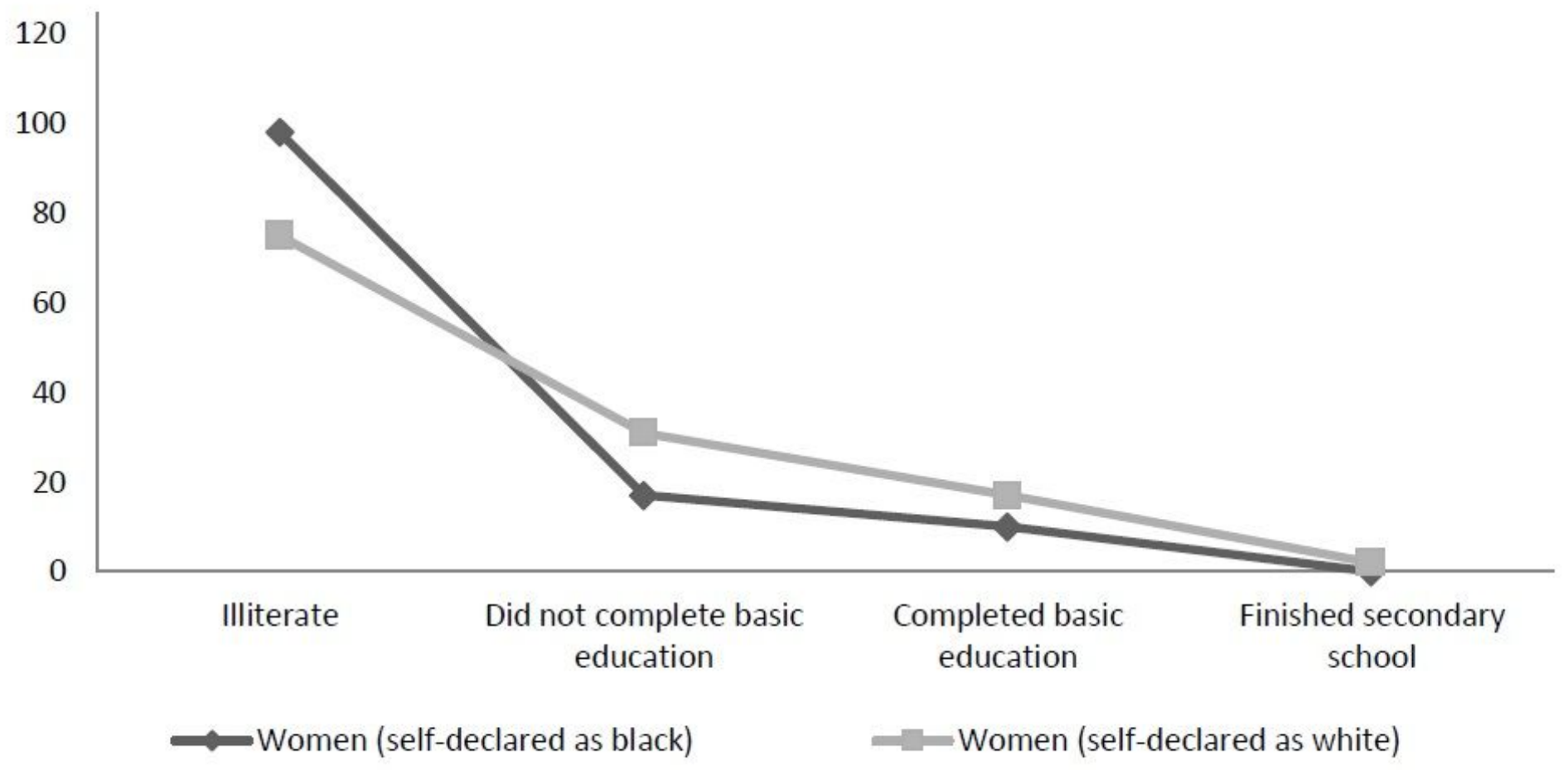

\section{Figure 3}

Schooling indicators among women by race/ethnicity. Source: Developed by the authors from the database.

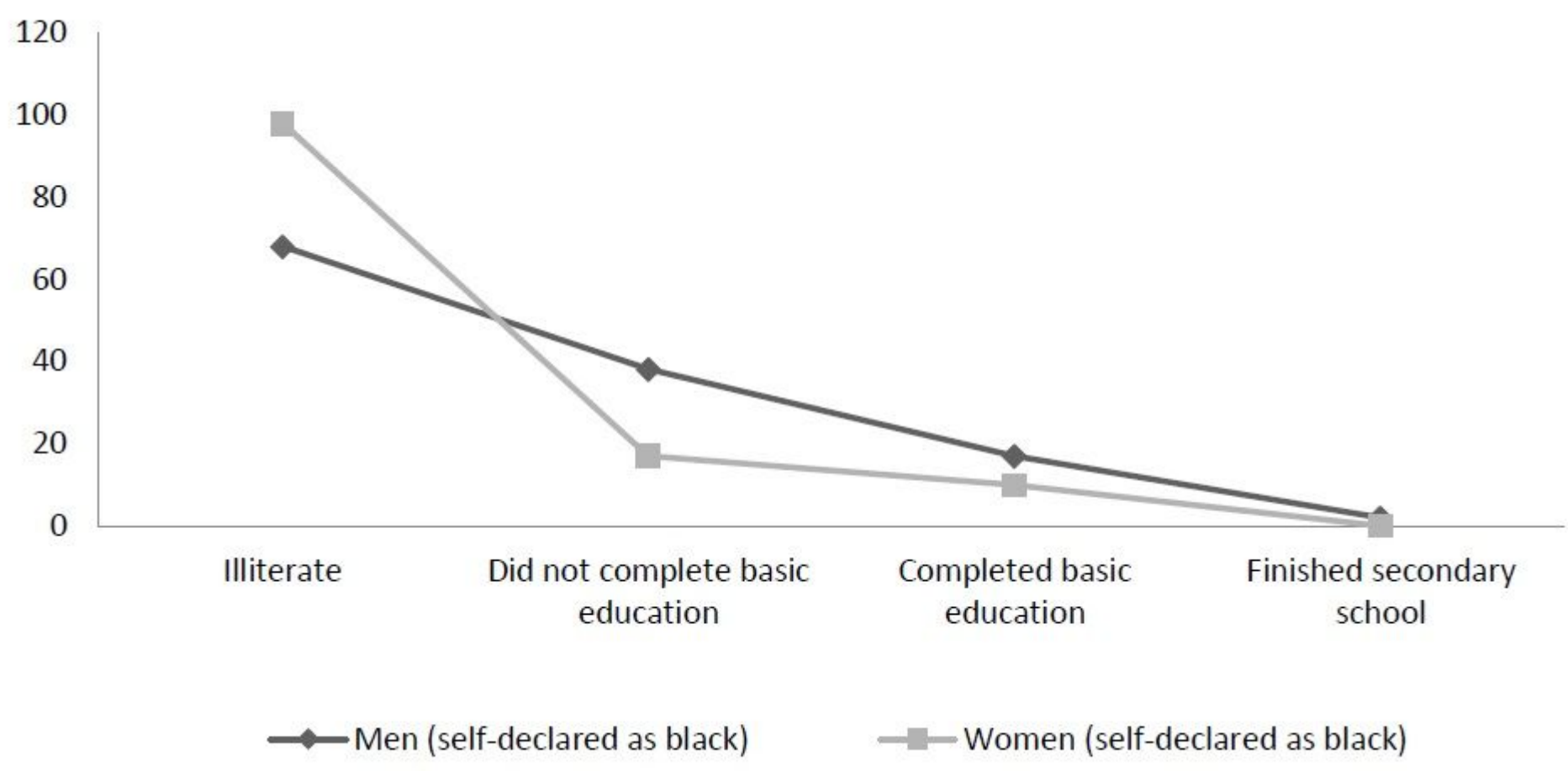

Figure 4 
Schooling indicators among men and women self-reported as black. Source: Developed by the authors from the database. 